\title{
Physicochemical properties of Doenjang using grain type Meju fermented by Aspergillus oryzae and protease
}

\author{
Na-Young Gil, Bo-Young Choi, Shin-Young Park, Yong-Sik Cho, So-Young Kim* \\ Fermented Food Science Division, Department of Agrofood Resources, National Institute of Agricultural Science, \\ RDA, Wanju 55365, Korea
}

\section{Aspergillus oryzae와 단백질 분해효소 첨가에 따른 콩알메주 된장의 이화학적 특성 변화}

\author{
길나영 · 최보영 · 박신영 · 조용식 · 김소영* \\ 농촌진흥청 국립농업과학원 농식품자원부 발효식품과
}

\begin{abstract}
The purpose of this study was to investigate the physiochemical properties of Doenjang was fermented by added with fungi and protease. The moisture content and pH of Doenjang added with protease (WP) were lower than those of control w/o protease while the contents of titratable acidity, reducing sugar, and amino-type nitrogen in WP were higher than control. The a-amylase activities of Doenjang added with single and mixed Protease B were the highest at 4 weeks of fermentation period and protease activity of WP was about 4 times higher than that of control. The 4-9 kinds of free amino acids (proline, isoleucine, leucine, and phenylalanine etc.) in WP was increased in comparison with control. The DPPH radical scavenging activity and total polyphenol content were higher in WP than control. Total aerobic bacterial and fungal numbers were decreased depending on fermentation time regardless of addition of protease. In conclusion, the protease can be used as additives improving the quality and taste of fermented Doenjang.
\end{abstract}

Key words : Doenjang, fermentation, protease, Aspergillus oryzae

\section{서 론}

한국의 전통장류 중 하나인 된장은 청국장, 간장 등과 함께 대두를 이용한 대표적인 단백질 급원식품으로 그대로 섭취하기 어려운 생 대두를 발효과정을 통하여 소화 흡수율 과 영양적 가치를 높인 콩 발효식품이다(1). 된장은 제조방 식에 따라 재래식과 개량식으로 구분하는데, 재래식 된장 은 찐 콩을 굳히면서 곰팡이나 세균에 의해 자연 발효된 메주를 소금물에 침지, 발효시켜 여액을 분리한 것이고,

*Corresponding author. E-mail : foodksy@korea.kr Phone : 82-63-238-3624, Fax : 82-63-238-3843

Received 2 August 2017; Revised 16 August 2017; Accepted 19 August 2017.

Copyright (c) The Korean Society of Food Preservation. All rights reserved.
반면 개량식 된장은 쌀, 밀 또는 보리 등의 전분질 원료에 선별된 종균을 이용하여 $\mathrm{koji}$ 를 제조하고 여기에 증자한 대두 및 소금을 혼합하여 숙성시켜 제조한 것이다(2). 여기 서 koji 제조 원리를 이용하여 증자한 대두 원료에 곰팡이 등 종균을 접종해서 발효시켜 만든 것이 콩알메주인데 이를 사용하여 제조한 개량식 된장이 콩알메주된장이다. 된장은 사용하는 국균, 원료, 그리고 지역별 기후 및 제조 특성 등 다양한 요인에 의해 맛 또는 제조방법을 표준화하기가 매우 어려운 식품이지만 생산업체 규모에 상관없이 전국적 으로 상당히 많은 곳에서 다양한 제품들이 생산되어 판매되 고 있다(3).

현재 재래식 된장은 제조기간이 오래 걸리고, 저장성을 높이기 위해 높은 염도에서 발효시키며, 자연발효로 인해 불필요하게 외부에서 혼입된 균으로 인한 부패나 변패와 같은 문제점을 지닌다. 개량식 된장의 경우에는 곰팡이를 
번식시키기 위해 전분질 원료를 사용하므로 콩 된장의 감칠 맛보다 단맛이 나고, 곰팡이인 Aspergillus oryzae를 접종하 여 된장을 발효시키므로 재래식 된장에서 자연적으로 증식 하는 Bacillus subtilis에 의한 고유한 풍미가 생성되지 않아 집집마다 전통으로 삼던 독특한 장맛을 내지 못하는 단점이 있다(4). 이러한 제조상 문제점을 보완하기 위해 증자한 콩 원형에 Aspergillus 및 Bacillus 등의 미생물을 접종해 콩알메주를 제조하여 메주의 제조 기간을 단축시키고 재래 식 된장의 감칠맛을 유지시키는 방법에 관한 연구가 수행되 었다. 대표적으로 감마선 조사된 개량메주의 품질특성(5), 벽돌형 개량메주의 품질특성(6), 콩알형 개량메주의 품질 수명(7), 국내에서 분리된 황국균을 활용한 된장 제조 및 특성 분석(8) 등이 보고되었으며, 이들은 주로 콩알메주를 이용한 된장의 일반적인 품질특성 변화를 살펴보았다.

단백질 분해효소(protease)는 단백질의 펩타이드 결합을 가수분해하는 효소로 동물 및 식물, 세균, 곰팡이, 효모, 바이러스 등 다양한 미생물에서 생산되며 식품, 사료, 의약, 섬유, 피혁, 세제공업, 정밀화학제품의 제조 등 다양하게 이용되고 있다(9). 식품 분야에서는 단백질 분해효소를 이 용하여 조미소재(10), 대두요구르트(11), 그리고 저식염 젓 갈(12) 등 발효식품을 제조하여 품질 특성을 살펴본 연구들 이 보고되어 있다. Chae 등(13)과 같이 일부에서는 단백질 분해효소 첨가 시 제조 기간을 단축할 수 있는 장점이 있지 만 자연발효 후 숙성하여 제조한 것에 비하여 풍미, 감칠맛 등이 부족하다는 단점을 가지고 있다고 보고하였다. 반면 Lee 등(14)은 콩 숙성에 관여하는 여러 미생물이 분비하는 protease, amylase 등의 효소에 의해 분해된 가용성분으로 인해 된장의 맛과 향이 결정될 수 있다고 언급하여 콩 단백 질의 가수분해를 촉진하기 위해 종균과 함께 단백질 분해효 소를 첨가하여 제조시간을 단축하면서 된장의 풍미 개선을 위한 연구가 필요하다.

이에 본 연구에서는 개량식 된장의 품질을 향상시키기 위하여 제조시간이 짧은 콩알메주를 Aspergillus oryzae를 접종하여 제조하였고 이 후 단백질 분해효소를 첨가하여 콩알메주 된장을 제조하였으며 가수분해물을 추출하여 이 화학적 특성 변화를 조사하였다.

\section{재료 및 방법}

\section{실험재료}

콩알 메주 및 증자콩은 대원콩을 이용하였으며, 콩알메 주에 사용한 균주는 메주에서 분리된 Aspergillus oryzae SCF-6로 순창장류연구소에서 제 공받았다. 사용효소는 단 백질 분해효소(protease)로 우리나라 장류식품에서 주로 분 리되고 특히 된장 발효에 관여하는 Baciillus속과 Aspergillus 속 중 시판되고 있는 Bacillus licheniformis에서 유래된
Alkaline protease(최적 pH 7-9)와 Aspergillus속에서 유래한 Promod 279(최적 $\mathrm{pH}$ 4-6)를 (주)비전바이오켐에서 구입하 여 이용하였다.

\section{콩알메주 제조}

콩알메주는 대두 품종 중 대표적인 대원콩을 이용하여 제조하였으며 Lee(15)의 방법을 변형하여 실시하였다. 먼 저 콩을 2 배 이상의 물로 15 시간 침지한 후 $121^{\circ} \mathrm{C}$ 에서 60 분 동안 증자하였다. 증자 된 콩을 $40^{\circ} \mathrm{C}$ 이하의 온도로 식힌 후 $A$ oryzae를 접종하여 $30^{\circ} \mathrm{C}, 80 \% \mathrm{RH}$ 에서 40 시간 발효시 켰다. 이때 $A$ oryzae 배양액은 $1 \times 10^{7}$ spore $/ \mathrm{mL}$ 농도가 되도 록 배양하여 대두 무게의 $1 \%(\mathrm{v} / \mathrm{w})$ 가 되도록 첨가하였다.

\section{된장 제조}

Lee 등(9)의 방법에 따라 된장 제조를 수행하였으며, 제 조된 콩알메주에 증자콩, 소금, 물을 혼합하여 소금농도 $13 \%$ 로 조정하였다. 이렇게 제조한 된장에 단백질 분해효소 를 Alkaline protease(Protease A, 1\%), Promod 279(Protease B, 1\%), Alkaline protease(A, 0.5\%)+Promod 279(B, 0.5\%)를 첨가, 혼합하여 3 시간 후에 0 주차 시료를 채취하였고, 8 주 동안 $30^{\circ} \mathrm{C}$ 에서 발효시켜 시료로 사용하였다.

\section{시료액 제조}

콩알메주 된장의 시료액은 시료 $8 \mathrm{~g}$ 을 증류수로 5 배 희석 하고 homogenizer(Polytron PT-MR 2100, Kinematica AG, Lucerne, Switzerland)로 1분간 조직을 파괴한 후 $8,000 \mathrm{rpm}$ 에서 10 분간 원심분리(Supra $25 k$, Hanil Co., Ltd., Incheon, Korea)하여 상층액을 취해 시료액으로 사용하였다.

\section{수분 및 염도}

콩알메주 된장의 수분 함량은 $\mathrm{AOAC}$ 법(16)에 따라 10 $5^{\circ} \mathrm{C}$ 상압건조법에 의해 분석하였다. 즉, 시료 $2 \mathrm{~g}$ 을 $105^{\circ} \mathrm{C}$ drying oven(MOV-112, Sanyo Co., Ltd., Osaka, Japan)에서 항량이 될 때까지 건조시켜 백분율(\%)로 나타내었다.

염도는 Mohr 법(17)에 따라 시료액 $10 \mathrm{~mL}$ 에 지시약인 $5 \% \mathrm{~K}_{2} \mathrm{CrO}_{4}$ 를 첨가하고 $0.1 \mathrm{~N} \mathrm{AgNO}_{3}$ 용액으로 미적갈색이 될 때까지 적정하여 염소량을 측정 한 후 $\mathrm{NaCl}$ 량으로 환산 하였다.

\section{$\mathrm{pH}$ 및 적정산도}

콩알메주 된장의 $\mathrm{pH}$ 는 시료액에 $\mathrm{pH}$ meter(Orion star a211, Thermo Scientific, Waltham, MA, USA)를 이용하여 측정하였고 적정산도는 $\operatorname{Jin}(18)$ 등의 방법에 따라 시료액 $10 \mathrm{~mL}$ 에 $0.5 \%$ 페놀프탈레인 지시약을 넣고 $0.1 \mathrm{~N} \mathrm{NaOH}$ 로 미적색이 될 때까지 적정하여 그 함량을 계산하였다.

\section{환원당 및 아미노태 질소}

콩알메주 된장의 환원당은 dinitrosalicylic acid(DNS) 방 
법(19)에 따라 시료액 $1 \mathrm{~mL}$ 에 DNS용액 $3 \mathrm{~mL}$ 을 혼합한 후 끓는 물에 5 분간 중탕하여 실온으로 냉각시켰다. microplate reader(Biotek Synergy Mx, Biotek Instruments, Winooski, $\mathrm{VT}, \mathrm{USA}$ )를 사용하여 $550 \mathrm{~nm}$ 의 파장으로 흡광도를 측정하 여 표준물질로 glucose를 사용하여 검량선을 그려 상대적인 함량을 계산하였다. 아미노태 질소는 시료액 $5 \mathrm{~mL}$ 에 중성 formalin 용액 $10 \mathrm{~mL}$ 과 증류수 $10 \mathrm{~mL}$ 을 넣은 본 시험과 시료액 $5 \mathrm{~mL}$ 에 증류수 $20 \mathrm{~mL}$ 을 넣은 공시험에 $0.5 \%$ 페놀프 탈레인 지시약을 넣고 $0.1 \mathrm{~N} \mathrm{NaOH}$ 를 이용하여 $\mathrm{pH}$ 8.4(미적 색)가 되도록 중화 적정하여 아미노태 질소 함량(\%)을 산출 하였다.

\section{색 도}

된장의 색도는 Ultrascan Pro(Pro Hunter Lab, Reston, VA, USA)를 사용하여 측정 후 Hunter scale의 L(lightness), $\mathrm{a}$ (redness), b(yellowness) 값으로 나타내었다(20). 이때 사용 한 표준 백색판(standardplate)의 색도는 L(99.52), a(-0.12), $\mathrm{b}(-0.16)$ 이었다.

\section{효소 활성}

a-amylase 활성은 $1 \%$ 전분 기질액 $1 \mathrm{~mL}$ 을 $40^{\circ} \mathrm{C}$ 에서 5 분 동안 예온하고 시료액 $50 \mu \mathrm{L}$ 를 넣어 반응시킨 반응액 50 $\mu \mathrm{L}$ 와 요오드용액 $5 \mathrm{~mL}$ 를 혼합한 용액과 $30^{\circ} \mathrm{C}$ 에서 30 분간 반응 시킨 후 반응액과 요오드용액의 $660 \mathrm{~nm}$ 의 파장으로 흡광도 측정한 값의 차를 이용하여 산출하였다(21).

protease 활성은 $0.6 \%$ casein 기질용액 $1 \mathrm{~mL}$ 과 시료액 $1 \mathrm{~mL}$ 을 $37^{\circ} \mathrm{C}$ 에서 10 분간 반응시킨 반응액에 $0.4 \mathrm{M}$ trichloroacetic acid(TCA) $2 \mathrm{~mL}$ 를 넣고 $37^{\circ} \mathrm{C}$ 에서 25 분간 반 응을 정지시킨 본 실험과 시료액 $1 \mathrm{~mL}$ 을 $37^{\circ} \mathrm{C}$ 에서 10 분간 방치한 후 $0.4 \mathrm{M} \mathrm{TCA} 2 \mathrm{~mL}$ 과 $0.6 \%$ casein 기질용액 1 $\mathrm{mL}$ 을 넣은 공시험구를 원심분리 $(8,000 \mathrm{rpm}, 5$ 분 $)$ 하였다. 상등액 $1 \mathrm{~mL}$ 과 $0.4 \mathrm{M} \mathrm{Na}_{2} \mathrm{CO}_{3} 5 \mathrm{~mL}$ 과 Folin 시약(1:3) 1 $\mathrm{mL}$ 을 넣어 $37^{\circ} \mathrm{C}$ 에서 20 분간 반응하여 발색시킨 후 660 $\mathrm{nm}$ 의 파장으로 흡광도를 측정하였고 표준곡선은 tyrosine 를 이용하여 산출하였다(22).

\section{유리 아미노산}

된장 중 유리아미노산 조성 분석을 위해 시료 $5 \mathrm{~g}$ 을 취하 여 $70 \%$ 에탄올 $100 \mathrm{~mL}$ 을 가하고 30 분 동안 진탕 추출한 후, 원심분리 $(8,000 \mathrm{rpm}, 10 \mathrm{~min})$ 하였다. 잔사에 $70 \%$ 에탄올 $50 \mathrm{~mL}$ 로 2회 반복 추출하고, 합한 추출액을 감압 농축한 후 $100 \mathrm{mg} / \mathrm{mL}$ 가 되도록 $70 \%$ 에탄올로 정용하여 시료 용액 으로 사용하였다. 시료 용액은 $0.45 \mu \mathrm{m}$ 의 syringe filter를 통과시켜 여과하여 Waters사의 AccQ-Tag Amino Acid Analysis 방법에 따라 유도체화하였다. 여과액 $10 \mu \mathrm{L}$ 에 AccQ-Fluor Borate Buffer $70 \mu \mathrm{L}$ 를 넣고 잘 혼합한 후, AccQ-Fluor Reagent $20 \mu \mathrm{L}$ 를 가하여 혼합한 다음에 상온에
서 1 분간 방치하였다. 이를 heating block을 이용하여 $55^{\circ} \mathrm{C}$ 에서 10 분간 가열한 후에 기기분석 조건(Column: AccQTagTM Ultra column, $2.1 \times 100 \mathrm{~mm}$, Flow rate: $0.7 \mathrm{~mL} / \mathrm{min}$, mobile phase: eluent A, eluent B, UV $260 \mathrm{~nm}$ )에 따라 UPLC(Acquity UPLC ${ }^{\circledR}$ system, Waters, Milford, MA, USA) 으로 분석하였다.

\section{$\mathrm{DPPH}$ 라디칼 소거 활성}

$\mathrm{DPPH}$ 라디칼 소거능 측정은 Lee 등(23)의 방법을 응용한 것으로 $70 \%$ 에탄올로 10 배 희석한 추출액 $0.2 \mathrm{~mL}$ 에 0.15 $\mathrm{mM} \mathrm{DPPH}$ 용액( $99 \%$ 에탄올 용해) $0.8 \mathrm{~mL}$ 를 넣고 혼합하 고, 30분 동안 암실에 방치 후 $517 \mathrm{~nm}$ 에서 흡광도를 측정하 였다. DPPH radical 소거 활성은 다음의 계산식을 이용하여 계산하였다.

$\mathrm{DPPH}$ radical 소거 활성 $(\%)=($ 대조군의 흡광도-시료군의 흡광도)/대조군의 흡광도×100

\section{총 폴리페놀 함량}

된장 시료의 총 폴리페놀 함량 측정은 Folin-ciocalteu's법 (24)을 응용한 것으로 에탄올 추출물 $250 \mu \mathrm{L}$ 에 folin ciocalteu reagent $1 \mathrm{~mL}$ 와 $1 \mathrm{~N} \mathrm{Na}_{2} \mathrm{CO}_{3} 2 \mathrm{~mL}$ 를 가하여 혼합한 다음 1 시간 동안 암실에서 방치한 후 분광광도계를 사용하 여 $765 \mathrm{~nm}$ 에서 흡광도를 측정하였다. 총 폴리페놀 함량은 표준물질로 tannic acid를 이용하여 표준곡선을 작성한 후 환산하여 나타내었다.

\section{미생물수}

된장 중 총 균수와 곰팡이수의 변화를 측정하기 위하여 각 시료 $1 \mathrm{~g}$ 을 멸균 생리식염수로 십진 희석한 후, 일정량을 취하여 총 균수는 tryptic soy $\operatorname{agar}\left(30^{\circ} \mathrm{C}, 24\right.$ 시간), 곰팡이는 potato dextrose $\operatorname{agar}\left(30^{\circ} \mathrm{C}, 48\right.$ 시간)에 도말하여 배양한 후 형성된 집락을 계수하여 산출하였다.

\section{통계적 처리}

모든 실험은 3 회 반복 측정하였고, 결과는 평균값 \pm 표준 편차로 나타내었다. 각 실험구 간의 유의성 $(\mathrm{p}<0.05)$ 검증을 위해 통계적 분석은 SAS(Statistical Analysis System program, SAS Institute., Cary, NC, USA) 프로그램을 이용하 여 분산분석(analysis of variance, ANOVA)한 후 Duncan's multiple range test로 다중비교를 실시하였다.

\section{결과 및 고찰}

\section{수분 및 염도 함량}

된장 제조 시간을 단축하기 위하여 $A$ oryzae 곰팡이를 
종균으로 하여 담근 콩알메주된장에 단백질 분해효소를 처리하여 된장 중 단백질 가수분해물의 이화학적 특성 변화 를 살펴보았다.

먼저 콩알메주 된장의 수분함량 및 염도 변화를 측정하 여 Table 1에 나타내었다. 된장의 수분함량은 단백질 분해 효소 첨가 된장의 경우 56.24-58.17\%로 무첨가 된장의 $57.05-59.30 \%$ 보다 낮은 수분함량을 보였고, 발효가 진행됨 에 따라 점차 감소하는 경향을 보였다. 특히 단백질 분해효 소 첨가 된장의 경우 담금 초기에는 그다지 뚜렷한 차이를 보이지 않다가 발효 8 주차에 유의적으로 감소하는 경향을 보였다(p<0.05). Kim 등(25)은 단백질 분해효소 생성 곰팡 이로 제조된 된장의 경우 초기 $52.9 \%$ 에서 발효 90 일 후 $48.6 \%$ 로 감소하였으며, 이는 발효 중 수분의 증발에 의한 것이라고 보고하여 본 실험결과와 마찬가지로 단백질 분해 효소에 의해 수분함량이 낮아지는 비슷한 경향을 나타내었 다.

된장의 염도는 단백질 분해효소 첨가 및 발효시간의 경 과에 따른 뚜렷한 변화가 관찰되지 않았는데, 이는 Choi 등(26)의 보고에서도 다양한 염도에서 제조한 된장이 발효 기간 경과에도 불구하고 담금 초기의 염도 값에서 큰 변화 가 없었다는 보고와 유사한 경향을 보였다.

\section{$\mathrm{pH}$ 및 적정산도}

단백질 분해효소 처리가 콩알메주된장 중 산 생성에 미 치는 영향을 살펴보기 위해 $\mathrm{pH}$ 와 적정산도를 측정하여
Table 1에 나타내었다. 된장의 $\mathrm{pH}$ 는 단백질 분해효소 첨가 된장의 경우 5.60-5.90, 무첨가 된장의 5.68-5.95를 보여 효 소 첨가에 따른 $\mathrm{pH}$ 변화는 없었지만, 단백질 분해효소 첨가 된장의 경우 발효 8 주차에 Protease $\mathrm{A}, \mathrm{A}+\mathrm{B}, \mathrm{B}$ 처리군 순으 로 유의적으로 높은 $\mathrm{pH}$ 를 나타내었으며, 발효시간의 경과 에 따라서는 유의적으로 점차 감소하는 경향을 보였다 ( $\mathrm{p}<0.05)$.

된장의 적정산도는 단백질 분해효소 첨가 된장의 경우 0.98-1.98\%로 무첨가 된장의 0.85-1.80\%보다 높은 산도값 을 보였고, Protease B 첨가 된장의 경우 발효 초기 $0.98 \%$ 로 낮은 적정산도를 보였지만 시간의 흐름에 따라 큰 폭으로 증가하여 발효 8 주차에 $1.98 \%$ 로 가장 높은 값을 나타내어 Protease A 첨가 된장과도 차이를 보였으나, 모든 실험구에 서 발효가 진행됨에 따라 유의적으로 증가하는 경향을 보였 다(p<0.05). 이는 된장이 미생물 대사 작용으로 인해 생성되 는 유기산의 증가로 산도가 증가하였고, 이에 따라 $\mathrm{pH}$ 도 감소한 것으로 판단되는데, Park 등(27)의 보고에서 된장 저장 중 일어나는 $\mathrm{pH}$ 감소와 산도의 증가는 발효 중에 생성 되는 산에 의한 영향이라 하였고, 염도, 발효온도 등에 따라 상당한 차이를 보인다고 언급하였다. 또한 단백질 분해효 소들 간에 $\mathrm{pH}$ 및 산도 차이는 사용한 효소들의 최적 $\mathrm{pH}$ 가 달라 나타난 현상으로 된장 내 산성 환경이 Protease B가 활성화하는데 좀 더 적합한 것으로 판단된다.

Table 1. Proximate composition of Doenjang fermented with Aspergillus oryzae SCF-6 and protease

\begin{tabular}{|c|c|c|c|c|c|c|c|}
\hline Group ${ }^{1)}$ & $\begin{array}{l}\text { Time } \\
\text { (weeks) }\end{array}$ & Moisture (\%) & Salinity (\%) & $\mathrm{pH}$ & Titratable acidity $(\%)$ & Reducing sugar (\%) & $\begin{array}{l}\text { Aminotype nitrogen } \\
(\mathrm{mg} \%)\end{array}$ \\
\hline \multirow{4}{*}{ Control } & 0 & $59.30 \pm 0.16^{\mathrm{Aa} 2)}$ & $13.36 \pm 0.18^{\mathrm{Aa}}$ & $5.95 \pm 0.01^{\mathrm{Aa}}$ & $0.85 \pm 0.10^{\mathrm{Cc}}$ & $2.83 \pm 0.61^{\mathrm{Aa}}$ & $152.60 \pm 5.05^{\mathrm{Cd}}$ \\
\hline & 2 & $58.25 \pm 0.26^{\mathrm{Ab}}$ & $13.35 \pm 0.23^{\mathrm{Aa}}$ & $5.91 \pm 0.00^{\mathrm{Ab}}$ & $1.52 \pm 0.00^{\mathrm{Bb}}$ & $3.41 \pm 0.13^{\mathrm{Ca}}$ & $595.94 \pm 1.40^{\mathrm{Dc}}$ \\
\hline & 4 & $58.09 \pm 0.20^{\mathrm{Ab}}$ & $13.34 \pm 0.07^{\mathrm{Aa}}$ & $5.78 \pm 0.00^{\mathrm{Ac}}$ & $1.76 \pm 0.14^{\mathrm{Aa}}$ & $3.19 \pm 0.20^{\mathrm{Ba}}$ & $863.99 \pm 9.77^{\mathrm{Ca}}$ \\
\hline & 8 & $57.05 \pm 0.27^{\mathrm{Ac}}$ & $13.45 \pm 0.12^{\mathrm{Aa}}$ & $5.68 \pm 0.00^{\mathrm{Ad}}$ & $1.80 \pm 0.00^{\mathrm{Da}}$ & $2.90 \pm 0.35^{\mathrm{BCa}}$ & $823.57 \pm 9.93^{\mathrm{Db}}$ \\
\hline \multirow{4}{*}{ Protease A } & 0 & $57.65 \pm 0.26^{\mathrm{Ba}}$ & $13.37 \pm 0.06^{\mathrm{Aa}}$ & $5.90 \pm 0.01^{\mathrm{Ba}}$ & $1.18 \pm 0.10^{\mathrm{Ac}}$ & $2.73 \pm 0.10^{\mathrm{Ab}}$ & $178.27 \pm 2.14^{\mathrm{Bd}}$ \\
\hline & 2 & $57.89 \pm 0.73^{\mathrm{Aa}}$ & $13.35 \pm 0.18^{\mathrm{Aa}}$ & $5.89 \pm 0.00^{\mathrm{Bb}}$ & $1.80 \pm 0.09^{\mathrm{Ab}}$ & $3.28 \pm 0.10^{\mathrm{Cab}}$ & $674.17 \pm 4.28^{\mathrm{Cc}^{2}}$ \\
\hline & 4 & $57.73 \pm 0.24^{\mathrm{Aa}}$ & $13.35 \pm 0.07^{\mathrm{Aa}}$ & $5.73 \pm 0.01^{\mathrm{Bc}}$ & $1.81 \pm 0.03^{\mathrm{Ab}}$ & $3.72 \pm 0.66^{\mathrm{Ba}}$ & $900.92 \pm 6.98^{\mathrm{Aa}}$ \\
\hline & 8 & $56.77 \pm 0.41^{\mathrm{ABb}}$ & $13.27 \pm 0.10^{\mathrm{ABa}}$ & $5.63 \pm 0.00^{\mathrm{Bd}}$ & $1.98 \pm 0.00^{\mathrm{Ca}}$ & $2.72 \pm 0.16^{\mathrm{Cb}}$ & $885.55 \pm 9.79^{\mathrm{Cb}}$ \\
\hline \multirow{4}{*}{ Protease B } & 0 & $57.42 \pm 0.28^{\mathrm{Ba}}$ & $13.15 \pm 0.13^{\mathrm{ABa}}$ & $5.89 \pm 0.01^{\mathrm{Ca}}$ & $0.98 \pm 0.01^{\mathrm{BCd}}$ & $3.30 \pm 0.66^{\mathrm{Ac}}$ & $146.53 \pm 2.14^{\mathrm{Dd}}$ \\
\hline & 2 & $57.72 \pm 0.08^{\mathrm{Aa}}$ & $13.09 \pm 0.07^{\mathrm{ABa}}$ & $5.84 \pm 0.01^{\mathrm{Cb}}$ & $1.70 \pm 0.01^{\mathrm{Ac}}$ & $4.14 \pm 0.22^{\mathrm{Aab}}$ & $736.34 \pm 0.81^{\mathrm{Bc}}$ \\
\hline & 4 & $57.68 \pm 0.20^{\mathrm{Aa}}$ & $13.06 \pm 0.07^{\mathrm{Ba}}$ & $5.68 \pm 0.01^{\mathrm{Dc}}$ & $1.84 \pm 0.09^{\mathrm{Ab}}$ & $4.58 \pm 0.05^{\mathrm{Aa}}$ & $803.57 \pm 9.09^{\mathrm{Db}}$ \\
\hline & 8 & $56.24 \pm 0.24^{\mathrm{Bb}}$ & $13.11 \pm 0.10^{\mathrm{Ba}}$ & $5.58 \pm 0.00^{\mathrm{Dd}}$ & $1.98 \pm 0.00^{\mathrm{Aa}}$ & $3.56 \pm 0.26^{\mathrm{Abc}}$ & $923.06 \pm 3.50^{\mathrm{Ba}}$ \\
\hline \multirow{4}{*}{ Protease $A+B$} & 0 & $57.78 \pm 0.32^{\mathrm{Ba}}$ & $13.09 \pm 0.12^{\mathrm{Ba}}$ & $5.87 \pm 0.00^{\mathrm{Da}}$ & $1.04 \pm 0.05^{\mathrm{ABc}}$ & $3.03 \pm 0.58^{\mathrm{Ab}}$ & $210.00 \pm 1.40^{\mathrm{Ad}}$ \\
\hline & 2 & $58.17 \pm 0.07^{\mathrm{Aa}}$ & $13.04 \pm 0.07^{\mathrm{Ba}}$ & $5.84 \pm 0.01^{\mathrm{Cb}}$ & $1.74 \pm 0.06^{\mathrm{Ab}}$ & $3.70 \pm 0.04^{\mathrm{Ba}}$ & $787.01 \pm 4.91^{\mathrm{Ac}}$ \\
\hline & 4 & $57.87 \pm 0.21^{\mathrm{Aa}}$ & $13.08 \pm 0.07^{\mathrm{Ba}}$ & $5.69 \pm 0.00^{\mathrm{Cc}}$ & $1.75 \pm 0.13^{\mathrm{Ab}}$ & $3.79 \pm 0.09^{\mathrm{Ba}}$ & $882.60 \pm 9.80^{\mathrm{Bb}}$ \\
\hline & 8 & $56.49 \pm 0.17^{\mathrm{Bb}}$ & $13.10 \pm 0.23^{\mathrm{Ba}}$ & $5.60 \pm 0.01^{\mathrm{Cd}}$ & $1.98 \pm 0.00^{\mathrm{Ba}}$ & $3.21 \pm 0.17^{\mathrm{ABa}}$ & $1,003.97 \pm 9.79^{\mathrm{Aa}}$ \\
\hline
\end{tabular}

\footnotetext{
${ }^{1)}$ Protease A isolated from Bacillus licheniformis, Protease B isolated from Aspergillus species, Protease A+B=0.5:0.5 ratio.

${ }^{2)}$ Any means in the same fermentation time $(A-B)$ or enzyme $(a-d)$ followed by different letters are significantly $(p<0.05)$ different by Duncan's multiple range test.
} 


\section{환원당 및 아미노태 질소 함량}

콩알메주 된장 중 생성된 환원당 및 아미노태 질소 함량 변화를 살펴보고 Table 1에 그 값을 제시하였다. 된장 발효 과정 중 미생물이 내는 가수분해효소에 의해 탄수화물 일부 가 분해되어 환원당이 생성되는데, 단백질 분해효소 첨가 된장 중 Protease $\mathrm{B}$ 를 첨가한 시료들은 높은 환원당 함랑을 나타낸 반면, Protease $\mathrm{A}$ 를 첨가한 된장의 경우 발효 4주차 를 제외하고 무첨가 된장보다 낮은 환원당 값을 보였다. 이 결과는 Park 등(28)이 언급한 대로 발효초기에 미생물이 생육하면서 분비한 탄수화물 분해효소에 의해 가수분해되 어 생성된 환원당 함량이 점차 증가하였고, 일정 발효기간 이 경과한 이후에 된장 내 미생물의 영양원으로 소모 또는 유기산 발효의 기질로 이용되면서 알코올로 분해되어 감소 하는 것으로 사료된다.

Table 1에 나타낸 바와 같이 된장의 아미노태 질소는 단백질 분해효소 첨가 된장의 경우 Protease $\mathrm{A}+\mathrm{B}$ 혼합처리 구에서 $1,003.97 \mathrm{mg} \%$ 로 가장 높은 아미노태 질소값을 보였 고, 단백질 분해효소 무첨가 된장의 경우 발효 8 주차에 $823.57 \mathrm{mg} \%$ 로 가장 낮은 아미노태 질소값을 보였으
며, 무첨가 된장과 Protease A 첨가 된장은 4주차에 가장 높은 값을 나타내었고, Protease B 첨가 된장과 Protease $\mathrm{A}+\mathrm{B}$ 혼합첨가 된장은 8 주차에 유의적으로 가장 높은 값을 나타내었다(p<0.05). $\mathrm{Kim}$ 등(29)의 시판 재래식 된장의 아 미노태 질소는 $252.0-557.0 \mathrm{mg} \%$ 로 본 실험의 발효 8주차의 결과보다 낮은 값을 나타내었고, 시판된장의 경우 숙성정 도가 다양하기 때문에 시료마다 차이가 있을 수 있다고 언급하였다. 따라서 단백질 분해효소 처리로 인해 된장 중 단백질 가수분해에 도움을 주면서 아미노산 등이 지속적으 로 생성되어 아미노태 질소 함량이 높은 것으로 사료된다.

\section{색 도}

단백질 분해효소 처리가 콩알메주 된장의 색도 변화에 미치는 영향을 조사하여 Fig. 1에 나타내었다. 된장의 색도 는 효소처리 유무와 관계없이 명도(L)와 황색도(b)는 발효 가 진행됨에 따라 점차 감소하는 경향을 보인 반면, 적색도 (a)와 변색도 $(\mathrm{dE})$ 값은 효소처리에 의해 발효 전후 각각 7.04에서 15.48로, 45.31에서 62.70으로 유의적인 변화를
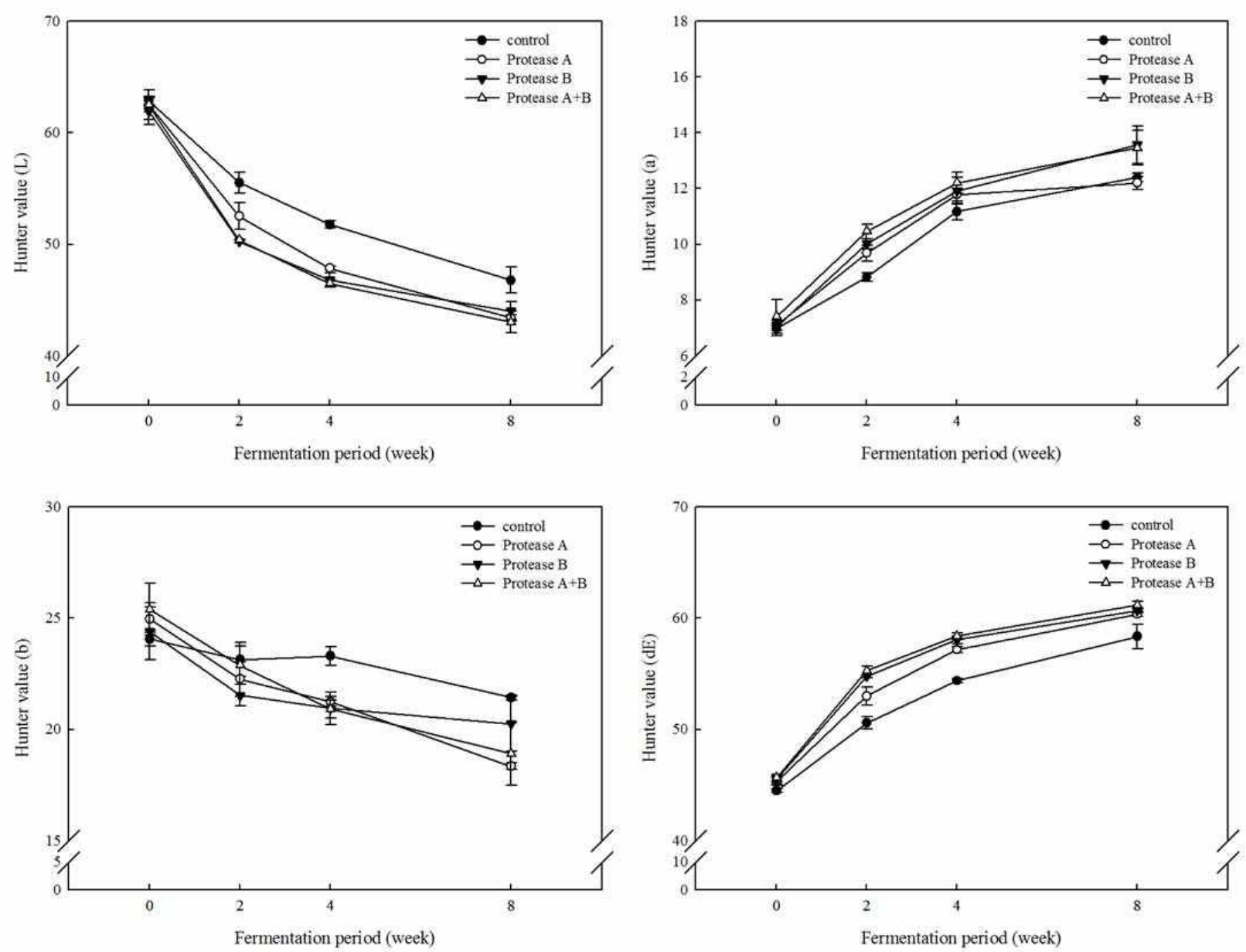

Fig. 1. Color change of Doenjang fermented with Aspergillus oryzae SCF-6 and protease. 
나타내어 무처리 된장에 비해 높아졌다. No 등(30)의 콩알 메주된장의 경우 제조 직후에 $\mathrm{L}$ 값은 45.79-49.22, a 값은 6.06-7.54, b 값은 14.91-17.22에서 발효 60일 후 L 값은 $38.56-43.67$, a 값은 7.99-9.32, b 값은 11.24-14.38로 L, b 값은 감소하고 $\mathrm{a}$ 값은 증가하여 본 실험과 비슷한 결과를 나타내었다.

\section{효소 활성}

단백질 분해효소 처리가 콩알메주 된장 중 생성된 전분 분해효소 및 단백질 분해효소 활성에 미치는 영향을 살펴본 후 Table 2에 그 값을 나타내었다. 된장의 a-amylase 활성은 Protease B와 Protease A+B 혼합처리구의 경우 발효 4주차 까지 각각 0.52 unit/g과 0.44 unit/g으로 활성이 증가하다가 이후로 점차 감소하는 경향을 보였고, Protease $\mathrm{A}$ 첨가 된장 과 무첨가 된장의 경우 발효초기부터 $0.06 \mathrm{unit} / \mathrm{g}$ 로 낮은 값을 나타내다가 발효 8 주차에 $0.03 \mathrm{unit} / \mathrm{g}$ 로 활성을 거의 나타내지 않았다. Joo 등(31)의 $A$ oryzae를 이용한 된장의 경우 0 일차부터 60 일까지 증가와 감소를 반복하다가 이후 에 현저히 감소하는 경향을 보였고, $\operatorname{Kim}(21)$ 에 의하면 담금 초기 된장의 원료인 콩에 소량 함유되어 있는 탄수화물이 amylase의 기질이 됨에 따라 효소 활성이 높았다가 발효가 진행되면서 기질이 소모되어 그 활성이 떨어진 것으로 보고 하였는데, 단백질 분해효소 무첨가 된장과 Protease A (alkaline) 첨가 된장의 경우 Protease B 첨가 된장과 Protease $\mathrm{A}+\mathrm{B}$ 혼합 처리한 된장 시료보다 낮은 환원당 함량을 보여 본 실험과 비슷한 경향을 보였다.

된장의 protease 활성은 단백질 분해효소를 첨가한 된장 의 경우 481.25-757.78 unit/g으로 발효 8주까지 증가와 감소 를 반복하였고, 무첨가 된장의 경우 168.06-261.25 unit/g으 로 발효 2주까지 증가하였다가 이후 감소하는 경향을 보여 가장 낮은 활성을 보였으며, 모든 시험구의 8 주차는
0 주차보다 낮은 단백질 분해효소 활성을 보였다. Kim등 (25)의 전통메주로부터 분리한 단백질 분해효소 생성 곰팡 이로 제조된 된장의 경우 발효 초기 75.39 unit/g에서 숙성 30 일에 $105.6 \mathrm{unit} / \mathrm{g}$ 으로 점차 증가하여 이후에는 계속 감소 하는 경향을 나타내었고, 이는 단백질 분해효소 작용으로 불용성 단백질이 가용성 단백질 또는 peptide 형태로 가수 분해 되어 활성도가 증가하지만 사용한 균주의 차이에 따라 큰 차이가 난다고 보고하였다.

\section{유리아미노산 조성}

콩알메주 된장의 효소처리 유무 및 발효기간 경과에 따 라 가수분해되어 생성된 유리아미노산 함량 변화를 측정하 여 Table 3에 나타내었다. 된장의 유리 아미노산은 단백질 분해효소 첨가 된장의 경우 Protease $\mathrm{A}, \mathrm{B}$, 그리고 $\mathrm{A}+\mathrm{B}$ 혼합처리 된장 모두 발효 전( 0 주차)과 발효 후(8주차)에 glutamic acid 함량이 가장 높은 값을 나타내었고, Protease $\mathrm{A}+\mathrm{B}$ 혼합처리구에서는 0 주차에 glutamic acid에서 8 주차에 phenylalanine으로 가장 높은 값을 나타내었고, 단백질 분해 효소 무첨가 된장의 경우 glutamic acid가 0 주차, 8 주차 모두 가장 높은 값을 나타내었다. 시간의 흐름에 따라 모든 실험 구에서 감칠맛을 내는 aspartic acid와 glutamic acid는 증가 하였고, 쓴맛을 내는 methionine과 valine은 감소, isoleucine, lucine, phenylalanine은 증가하였다. Kim과 Rhee(32)의 개 량식 된장의 유리아미노산 측정결과 glutamic acid 함량이 가장 높았으며, 다음으로 aspartic acid, leucine, lysine, alanine 순이라고 보고하였는데, 본 실험 결과와는 조금 다 른 경향을 보였지만, An 등(33)의 메주균을 달리하여 제조 한 된장의 유리아미노산은 $A$ oryzae구의 된장에서는 glutamic acid, phenylalanine, lucine이 높았다고 보고하여 본 실험과 유사한 경향을 보였다. 이는 된장 내 존재하는 미생물에 의해 생성된 단백질 분해효소의 작용으로 인

Table 2. Enzyme activity (unit/g) of Doenjang fermented with Aspergillus oryzae SCF-6 and protease

\begin{tabular}{|c|c|c|c|c|c|c|}
\hline & & \multicolumn{4}{|c|}{ Fermentation period (week) } & \multirow{2}{*}{ F-value } \\
\hline & & 0 & 2 & 4 & 8 & \\
\hline \multirow{4}{*}{ Alpha-amylase } & Control & $0.06 \pm 0.00^{\mathrm{Cab} 2)}$ & $0.06 \pm 0.02^{\mathrm{Ba}}$ & $0.05 \pm 0.02^{\mathrm{Cab}}$ & $0.03 \pm 0.01^{\mathrm{Cb}}$ & 0.1410 \\
\hline & Protease $A^{1)}$ & $0.06 \pm 0.02^{\mathrm{Ca}}$ & $0.06 \pm 0.01^{\mathrm{Ba}}$ & $0.05 \pm 0.00^{\mathrm{Cab}}$ & $0.03 \pm 0.00^{\mathrm{cb}}$ & 0.0110 \\
\hline & Protease B & $0.41 \pm 0.01^{\mathrm{Ab}}$ & $0.42 \pm 0.03^{\mathrm{Ab}}$ & $0.52 \pm 0.02^{\mathrm{Aa}}$ & $0.16 \pm 0.01^{\mathrm{Ac}}$ & $<0.0001$ \\
\hline & Protease $A+B$ & $0.38 \pm 0.00^{\mathrm{Bb}}$ & $0.45 \pm 0.04^{\mathrm{Aa}}$ & $0.44 \pm 0.02^{\mathrm{Ba}}$ & $0.12 \pm 0.04^{\mathrm{Bc}}$ & $<0.0001$ \\
\hline \multicolumn{2}{|c|}{ F-value } & $<0.0001$ & $<0.0001$ & $<0.0001$ & $<0.0001$ & \\
\hline \multirow{4}{*}{ Protease } & Control & $168.06 \pm 39.72^{\mathrm{Cb}}$ & $261.25 \pm 29.03^{\mathrm{Ca}}$ & $187.92 \pm 19.86^{\mathrm{Bb}}$ & $175.69 \pm 29.03^{\mathrm{Cb}}$ & 0.0191 \\
\hline & Protease A & $643.19 \pm 44.31^{\mathrm{Ba}}$ & $641.67 \pm 64.17^{\mathrm{Aa}}$ & $574.44 \pm 51.94^{\mathrm{Aab}}$ & $533.19 \pm 44.31^{\mathrm{Bb}}$ & 0.0815 \\
\hline & Protease B & $701.25 \pm 25.97^{\mathrm{ABa}}$ & $513.33 \pm 51.94^{\mathrm{Bbc}}$ & $569.86 \pm 13.75^{\mathrm{Ab}}$ & $481.25 \pm 29.03^{\mathrm{Bc}}$ & 0.0002 \\
\hline & Protease $A+B$ & $757.78 \pm 12.22^{\mathrm{Aa}}$ & $725.69 \pm 32.08^{\mathrm{Aab}}$ & $603.47 \pm 1.53^{\mathrm{Ac}}$ & $693.61 \pm 42.78^{\mathrm{Ab}}$ & 0.0007 \\
\hline \multicolumn{2}{|c|}{ F-value } & $<0.0001$ & $<0.0001$ & $<0.0001$ & $<0.0001$ & \\
\hline
\end{tabular}

\footnotetext{
${ }^{1)}$ Protease A isolated from Bacillus licheniformis, Protease B isolated from Aspergillus species, Protease A+B=0.5:0.5 ratio.

${ }^{2)}$ Any means in the same fermentation time $(A-B)$ or enzyme $(a-d)$ followed by different letters are significantly $(\mathrm{p}<0.05)$ different by Duncan's multiple range test.
} 
해 자연적으로 발효되면서 단백질 분해효소 무첨가 된장에 비해 증가한 아미노산은 Protease A 처리 시 arginine, lucine, tryptophan, phenylalanine 등 4종이고, $\mathrm{B}$ 처리한 경우 histidine, serine, glycine, threonine, proline, isoleucine, lucine, phenylalanine 등 8 종이며, $\mathrm{A}+\mathrm{B}$ 처리 시 histidine, serine, glycine, threonine, proline, tryptophan, isoleucine, lucine, phenylalanine 등 9종으로 Protease B가 Protease A에 비해 유리아미노산 생성에 더 깊이 관여하는 것으로 판단된다.

\section{$\mathrm{DPPH}$ 라디칼 소거 활성}

콩알메주 된장을 제조하여 효소처리 유무 및 발효 기간 경과에 따른 항산화 활성 변화를 비교하여 Table 4에 그 값을 제시하였다. 된장의 $\mathrm{DPPH}$ 라디칼 소거 활성은 단백질 분해효소 첨가 된장의 경우 Protease $\mathrm{B}$ 단독, $\mathrm{A}+\mathrm{B}$ 혼합처리 구, Protease A 단독처리구 순으로 높은 소거 활성을 나타내 었지만 통계적으로 유의적인 차이를 보이지는 않았고 ( $\mathrm{p}>0.05)$, 단백질 분해효소 무첨가 된장의 경우 $8.93-28.87 \%$

Table 3. Free amino acid content (ppm) of Doenjang fermented with Aspergillus oryzae SCF-6 and protease

\begin{tabular}{ccccccccc}
\hline \multirow{2}{*}{ Amino acids } & \multicolumn{2}{c}{ Control } & \multicolumn{2}{c}{ Protease $\mathrm{A}^{1)}$} & \multicolumn{2}{c}{ Protease B } & \multicolumn{2}{c}{ Protease A+B } \\
\cline { 2 - 8 } & 0 week & 8 week & 0 week & 8 week & 0 week & 8 week & 0 week & 8 week \\
\hline Histidine & $10.70 \pm 0.04$ & $22.53 \pm 1.23$ & $9.48 \pm 0.32$ & $21.81 \pm 0.70$ & $17.16 \pm 0.18$ & $26.15 \pm 0.91$ & $14.80 \pm 0.03$ & $26.85 \pm 2.41$ \\
Serine & $17.53 \pm 0.49$ & $41.72 \pm 1.70$ & $18.53 \pm 0.63$ & $40.26 \pm 0.48$ & $22.79 \pm 0.16$ & $44.30 \pm 0.35$ & $22.64 \pm 0.39$ & $44.64 \pm 5.46$ \\
Arginine & $17.72 \pm 1.03$ & $18.81 \pm 0.78$ & $21.44 \pm 0.84$ & $22.28 \pm 0.15$ & $55.73 \pm 2.78$ & $30.80 \pm 0.33$ & $47.82 \pm 0.10$ & $28.75 \pm 3.09$ \\
Glycine & $13.03 \pm 0.13$ & $33.71 \pm 0.85$ & $12.77 \pm 0.75$ & $32.18 \pm 0.71$ & $16.48 \pm 0.81$ & $38.55 \pm 0.72$ & $15.54 \pm 0.40$ & $37.49 \pm 3.49$ \\
Aspartic acid & $12.09 \pm 0.90$ & $38.91 \pm 3.08$ & $9.03 \pm 0.09$ & $25.37 \pm 3.04$ & $9.74 \pm 0.89$ & $29.92 \pm 1.21$ & $9.78 \pm 0.80$ & $27.82 \pm 4.71$ \\
Glutamic acid & $84.12 \pm 5.74$ & $137.32 \pm 8.42$ & $69.69 \pm 0.08$ & $96.76 \pm 9.36$ & $71.53 \pm 4.75$ & $100.58 \pm 3.15$ & $79.57 \pm 4.32$ & $98.33 \pm 12.67$ \\
Threonine & $14.67 \pm 0.13$ & $30.77 \pm 1.14$ & $14.61 \pm 0.16$ & $15.76 \pm 12.68$ & $19.82 \pm 0.11$ & $35.17 \pm 0.43$ & $18.72 \pm 0.25$ & $36.58 \pm 4.93$ \\
Alanine & $27.19 \pm 1.61$ & $40.87 \pm 1.35$ & $23.66 \pm 0.19$ & $33.23 \pm 2.30$ & $23.50 \pm 1.25$ & $35.11 \pm 0.18$ & $25.53 \pm 0.71$ & $33.72 \pm 3.68$ \\
Proline & $16.13 \pm 0.41$ & $35.84 \pm 0.67$ & $14.91 \pm 0.74$ & $31.94 \pm 0.59$ & $26.05 \pm 0.51$ & $47.83 \pm 0.40$ & $22.56 \pm 0.04$ & $42.42 \pm 2.94$ \\
Cysteine & $4.07 \pm 0.53$ & $0.17 \pm 0.02$ & $4.73 \pm 0.18$ & $0.20 \pm 0.07$ & $4.44 \pm 0.12$ & $0.27 \pm 0.01$ & $5.16 \pm 0.23$ & $0.33 \pm 0.07$ \\
Lysine & $42.60 \pm 2.53$ & $53.77 \pm 2.56$ & $34.98 \pm 2.21$ & $33.76 \pm 5.63$ & $40.85 \pm 4.09$ & $33.61 \pm 0.38$ & $45.03 \pm 2.25$ & $30.10 \pm 4.13$ \\
Tryptophan & $32.67 \pm 0.78$ & $44.04 \pm 0.28$ & $31.92 \pm 1.25$ & $48.88 \pm 3.07$ & $45.02 \pm 1.50$ & $40.95 \pm 1.28$ & $42.81 \pm 1.23$ & $46.42 \pm 5.08$ \\
Methionine & $11.19 \pm 0.24$ & $10.01 \pm 0.51$ & $11.88 \pm 0.02$ & $11.08 \pm 0.47$ & $13.94 \pm 0.26$ & $11.10 \pm 0.55$ & $15.11 \pm 0.05$ & $12.32 \pm 1.37$ \\
Valine & $23.79 \pm 1.52$ & $0.88 \pm 0.02$ & $18.99 \pm 0.03$ & $0.82 \pm 0.02$ & $29.06 \pm 1.61$ & $0.95 \pm 0.01$ & $28.17 \pm 0.38$ & $0.91 \pm 0.08$ \\
Isoleucine & $19.87 \pm 0.99$ & $49.81 \pm 1.02$ & $17.34 \pm 0.05$ & $46.67 \pm 1.14$ & $28.35 \pm 1.72$ & $56.05 \pm 0.79$ & $26.61 \pm 0.20$ & $54.47 \pm 4.56$ \\
Lucine & $50.88 \pm 2.47$ & $86.62 \pm 1.98$ & $54.73 \pm 0.14$ & $88.13 \pm 2.09$ & $69.01 \pm 4.38$ & $92.01 \pm 1.56$ & $72.35 \pm 0.26$ & $93.77 \pm 8.03$ \\
Phenylalanine & $47.51 \pm 1.16$ & $75.48 \pm 0.62$ & $51.68 \pm 1.95$ & $85.66 \pm 5.35$ & $68.33 \pm 0.47$ & $92.39 \pm 3.36$ & $65.18 \pm 2.23$ & $100.62 \pm 9.79$ \\
\hline
\end{tabular}

${ }^{1)}$ Protease A isolated from Bacillus licheniformis, Protease B isolated from Aspergillus species, Protease A+B=0.5:0.5 ratio.

Table 4. Antioxidant ability of Doenjang fermented with Aspergillus oryzae SCF-6 and protease

\begin{tabular}{|c|c|c|c|c|c|c|}
\hline & & \multicolumn{4}{|c|}{ Fermentation period (week) } & \multirow{2}{*}{ F-value } \\
\hline & & 0 & 2 & 4 & 8 & \\
\hline \multirow{4}{*}{ DPPH radical scavenging activity (\%) } & Control & $8.93 \pm 4.93^{\mathrm{Ab2} 2}$ & $12.04 \pm 0.49^{\mathrm{Bb}}$ & $22.45 \pm 2.90^{\mathrm{Aa}}$ & $28.87 \pm 3.75^{\mathrm{Aa}}$ & 0.0003 \\
\hline & Protease $A^{1)}$ & $13.20 \pm 4.81^{\mathrm{Ab}}$ & $18.74 \pm 2.74^{\mathrm{Ab}}$ & $26.69 \pm 2.18^{\mathrm{Aa}}$ & $30.45 \pm 2.07^{\mathrm{Aa}}$ & 0.0006 \\
\hline & Protease B & $12.51 \pm 2.50^{\mathrm{Ac}}$ & $23.52 \pm 0.49^{\mathrm{Ab}}$ & $25.01 \pm 2.96^{\mathrm{Ab}}$ & $33.98 \pm 1.20^{\mathrm{Aa}}$ & $<0.0001$ \\
\hline & Protease $A+B$ & $11.02 \pm 4.24^{\mathrm{Ac}}$ & $20.64 \pm 4.67^{\mathrm{Ab}}$ & $26.22 \pm 3.99^{\mathrm{Aab}}$ & $33.38 \pm 2.82^{\mathrm{Aa}}$ & 0.0008 \\
\hline F-value & & 0.6333 & 0.005 & 0.3899 & 0.2251 & \\
\hline \multirow{4}{*}{ Total phenol (mg TAE/g) } & Control & $0.60 \pm 0.06^{\mathrm{Ad}}$ & $0.92 \pm 0.10^{\mathrm{Bc}}$ & $1.66 \pm 0.05^{\mathrm{Ab}}$ & $1.86 \pm 0.08^{\mathrm{Ca}}$ & $<0.0001$ \\
\hline & Protease A & $0.77 \pm 0.13^{\mathrm{Ad}}$ & $1.11 \pm 0.12^{\mathrm{ABC}}$ & $1.50 \pm 0.06^{\mathrm{Bb}}$ & $2.01 \pm 0.09^{\mathrm{Ba}}$ & $<0.0001$ \\
\hline & Protease B & $0.78 \pm 0.11^{\mathrm{Ad}}$ & $1.26 \pm 0.04^{\mathrm{Ac}}$ & $1.56 \pm 0.00^{\mathrm{ABb}}$ & $2.24 \pm 0.01^{\mathrm{Aa}}$ & $<0.0001$ \\
\hline & Protease $A+B$ & $0.70 \pm 0.04^{\mathrm{Ad}}$ & $1.07 \pm 0.20^{\mathrm{ABc}}$ & $1.56 \pm 0.07^{\mathrm{ABb}}$ & $2.20 \pm 0.07^{\mathrm{Aa}}$ & $<0.0001$ \\
\hline F-value & & 0.1344 & 0.0633 & 0.0402 & 0.0005 & \\
\hline
\end{tabular}

\footnotetext{
${ }^{1)}$ Protease A isolated from Bacillus licheniformis, Protease B isolated from Aspergillus species, Protease $\mathrm{A}+\mathrm{B}=0.5: 0.5$ ratio.
}

${ }^{2)}$ Any means in the same fermentation time $(\mathrm{A}-\mathrm{B})$ or enzyme $(\mathrm{a}-\mathrm{d})$ followed by different letters are significantly $(\mathrm{p}<0.05)$ different by Duncan's multiple range test. 
로 가장 낮은 값을 보였으며, 모든 실험구에서 시간의 흐름 에 따라 증가하는 경향을 보였다(p<0.05). Ahn 등(34)은 $\mathrm{DPPH}$ 라디칼 소거능의 차이가 나타나는 것은 된장의 주원 료인 콩의 발효상태에 따라 콩 단백질로부터 분해된 아미노 산의 종류와 함량 차이에 의해 발생하는 것으로 보고하여 본 실험의 단백질 분해효소 첨가 된장의 경우 단백질 분해 효소 무첨가 된장보다 효소에 의해 아미노산의 함량이 증가 하여 높은 값을 나타낸 것으로 사료된다.

\section{총 폴리페놀 함량}

된장의 효소처리 및 발효기간 경과에 따른 총 폴리페놀 함량 변화를 살펴본 결과, 단백질 분해효소 첨가 된장의 경우 Protease B가 0.78-2.24 mg TAE/g으로 가장 높은 함량 을 나타내었고 $(\mathrm{p}<0.05)$, 무첨가 된장의 경우 발효 4 주차를 제외하고 $0.60-1.86 \mathrm{mg} \mathrm{TAE} / \mathrm{g}$ 으로 실험구 중 가장 낮은 값을 보였으며, 모든 실험구에서 발효가 진행되면서 총폴 리페놀 함량이 증가하는 경향을 보였다(p<0.05). $\mathrm{Ku}$ 등(35) 은 콩 등 식물체에 포함된 페놀성 화합물은 대사산물의 하나로 특히 phenolic hydroxyl기가 항산화 생리활성을 가 진다고 알려져 있어 발효 숙성 과정에서 페놀성 물질인 이소플라본 배당체가 aglycon 형태인 genistein과 daidzein 등으로 변환되어 발효되지 않은 콩보다 높은 항산화 활성을 가지는 것으로 보고하였는데, 이번 결과에서는 발효초기에 는 실험구간에 유의적으로 차이를 보이지 않았지만 발효가 진행됨에 따라 단백질 분해효소 첨가 된장의 경우 단백질 분해효소로 인해 폴리페놀 함량이 증가하면서 8 주차에는 유의적인 차이를 보여 콩 발효 시 이소플라본 등과 같은 유용한 폴리페놀 물질의 분리에도 관여하는 것으로 사료된 다.

\section{미생물수 측정}

단백질 분해효소 처리에 따른 발효기간 중 콩알메주 된
장의 미생물수 변화를 관찰하여 Fig. 2에 그 값을 제시하였 다. 콩알메주 된장 시료 중 총균수 변화는 단백질 분해효소 의 첨가 유무와 상관이 발효가 진행됨에 따라 증가와 감소 를 반복하였는데, 발효 8주차에서 7.76-7.98 $\log \mathrm{CFU} / \mathrm{g}$ 를 보여 0주차 8.15-8.50 $\log \mathrm{CFU} / \mathrm{g}$ 보다 낮은 값을 나타내었다. 된장 내 곰팡이수는 단백질 분해효소 첨가 유무와 상관없이 발효 초기에 6.45-5.65 log CFU/g 값을 나타내었다가 발효 기간 내 꾸준히 감소하는 경향을 보였으며, 발효 8 주차에 모든 실험구에서 전혀 검출되지 않았다. Lee 등(36)은 재래 식 된장의 경우 숙성 60 일 이후 호기성균이 $8 \log \mathrm{CFU} / \mathrm{g}$ 으 로 120 일까지 큰 변화가 없다고 보고하였고, Park 등(27) 역시 매실 첨가 된장의 경우 7.02 및 7.23에서 발효 8 주차에 6.69 및 $6.64 \log \mathrm{CFU} / \mathrm{g}$ 로 감소하였다고 언급하였으며, Rhee 등(37)이 보고한 표고버섯 첨가 된장에서도 시간의 흐름에 따라 감소하는 경향을 보여 본 실험결과와 유사한 경향을 보였다.

\section{요 약}

본 연구는 $A$ oryzae를 접종하여 제조한 콩알메주 된장에 단백질 분해효소를 처리한 후 아미노태 질소, 유리아미노 산 등 품질특성 변화를 조사하였다. 콩알메주 된장의 수분 함량 및 $\mathrm{pH}$ 는 단백질 분해효소 첨가 된장이 무첨가 된장보 다 낮은 결과를 보였고, 염도와 색도는 단백질 분해효소에 따른 변화가 없었으며, 적정산도, 환원당 및 아미노태 질소 는 단백질 분해효소 첨가 된장이 무첨가 된장보다 높은 결과를 보였다. a-amylase 효소활성은 Aspergillus속 유래 단백질 분해효소 단독 및 혼합처리 된장의 경우 발효 4 주차 에 가장 높은 활성을 보인 반면, 단백질 분해효소 무첨가 된장은 거의 활성을 나타내지 않았고, protease 효소활성은 단백질 분해효소를 첨가한 된장의 경우 무첨가 된장보다
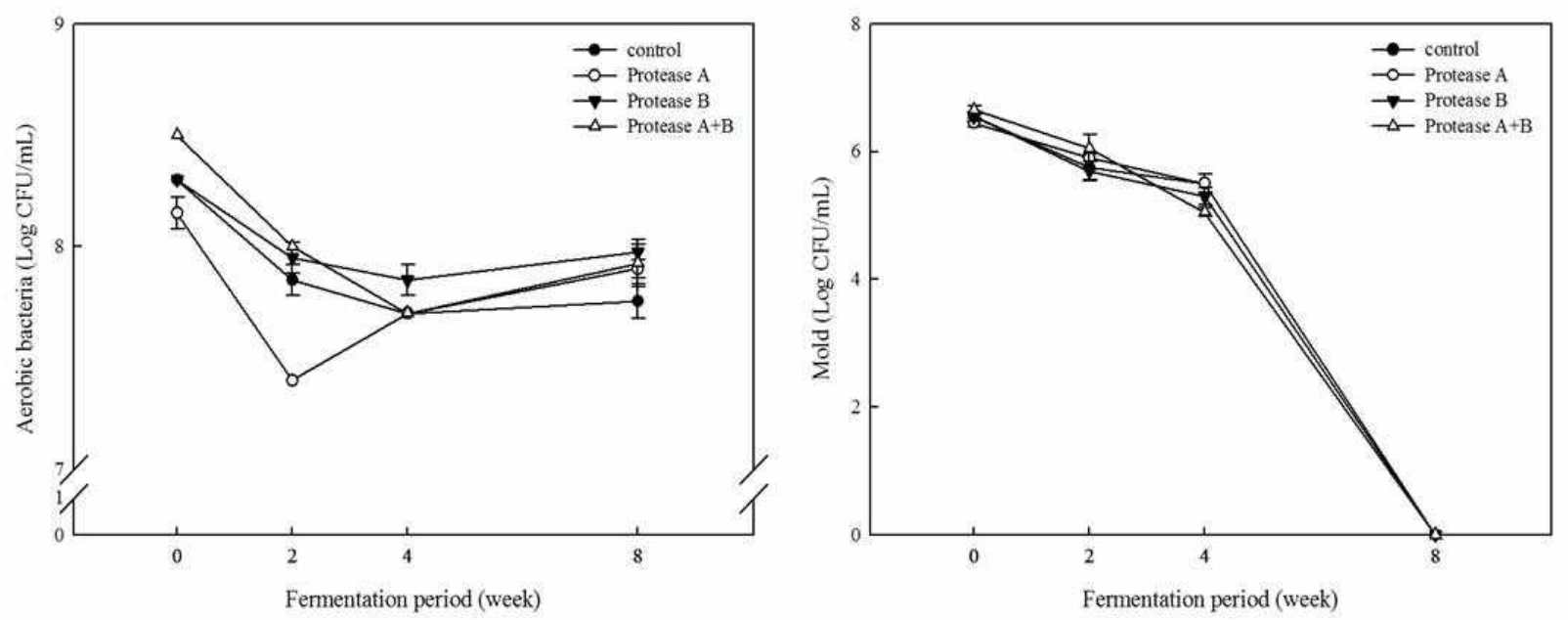

Fig. 2. Change on total bacterial and fungi number of Doenjang fermented with Aspergillus oryzae SCF-6 and protease. 
약 4배 높은 활성을 보였다. 무첨가 된장에 비해 단백질 분해효소처리 된장에서 Protease A 처리 시 arginine, lucine, tryptophan, phenylalanine 등 4종, Protease B 처리 시 histidine, serine, glycine, threonine, proline, isoleucine, lucine, phenylalanine 등 8 종, Protease $\mathrm{A}+\mathrm{B}$ 혼합처리 시 histidine, serine, glycine, threonine, proline, tryptophan, isoleucine, lucine, phenylalanine 등 9종의 유리아미노산이 증가하였다. $\mathrm{DPPH}$ 라디칼 소거 활성과 총 폴리페놀함량은 단백질 분해효소 첨가 된장의 경우 무첨가 된장보다 높은 값을 보였고, 총 균수와 곰팡이 수는 단백질 분해효소의 첨가 유무와 상관없이 발효가 진행됨에 따라 감소하였다. 이상의 결과를 종합하여 $A$ oryzae 접종 콩알메주 된장의 제조 시 단백질 분해효소를 첨가하여 발효시킬 경우 효소에 의해 환원당, 아미노태 질소 함량과 항산화능이 증가하고, a-amylase와 protease 등 효소활성이 높아 된장의 발효기간 을 단축시키면서 맛과 품질 개선에 도움이 될 것으로 기대 된다.

\section{감사의 글}

본 연구는 농촌진흥청 국립농업과학원 어젠다사업(과제 번호: PJ010927)의 지원에 의해 이루어진 것입니다.

\section{References}

1. Jeon DY, Yoon GB, Yoon YH, Yang SI, Kim JB (2016) Bacterial community of traditional Doenjang in longevity area and antagonistic effect against Bacillus cereus. J Korean Soc Food Sci Nutr, 45, 1035-1040

2. Lee SW, Park YW, Chang PS, Lee JH (2010) Isoflavone distribution and $\beta$-glucosidase activity in home-made and factory-produced Doenjang. Korean J Food Sci Technol, 42, 125-129

3. Kim DH, Kang SW, Kim SH (1999) Production of Korean traditional soy sauce from Rhizopus stolonifer inoculated grain type Meju. Korean J Food Sci Technol, 31, 757-763

4. Chang M, Chang HC (2007) Characteristics of bacterial-koji and Doenjang (soybean paste) made by using Bacillus subtilis DJI. Kor J Microbiol Biotechnol, 35, 325-333

5. Kim DH, Lee KH, Yook HS, Kim JH, Shin MG, Byun MW (2000) Quality characteristics of gamma irradiated-grain shape improved Meju. Korean J Food Sci Technol, 32, 640-645
6. Park CK, Nam JH, Song HI (1990) Studies on the shelf-life of the brick shape improved Meju. Korean J Food Sci Technol, 22, 82-87

7. Park CK, Nam JH, Song HI, Park HY (1989) Studies on the shelf-life of the grain shape improved Meju. Korean J Food Sci Technol, 21, 876-883

8. Lee RK, Cho HN, Shin MJ, Yang JH, Kim ES, Kim $\mathrm{HH}$, Cho SH, Lee JY, Park YS, Cho YS, Lee JM, Kim HY (2016) Manufacturing and quality characteristics of the Doenjang made with Aspergillus oryzae strains isolated in Korea. Microbiol Biotechnol Lett, 44, 40-47

9. Lee YK, Oh YS, Roh DH (2012) Production properties on extracellular protease from Chryseobacterium novel strain JK1. Korean J Microbiol, 48, 48-51

10. Lee KH, Song BK, Jeong IH, Hong BI, Jung BC, Lee DH (1997) Processing condition of seasoning material of the mixture of laminaria and enzyme-treated mackerel meat. Korean J Food Sci Technol, 29, 77-81

11. Ko YT (1989) Acid production by lactic acid bacteria in soy milk treated by microbial pretense or papain and preparation of soy yogurt. Korean J Food Sci Technol, 21, 379-386

12. Cha YJ, Lee EH (1989) Studies on the processing of rapid fermented anchovy prepared with low salt contents by adapted microorganism. Bull Korean Fish Soc, 22, 363-369

13. Chae HJ, In MJ, Kim MH (1997) Production and characteristics of enzymatically hydrolyzed soy sauce by the treatment using proteases. J Korean Soc Food Sci Nutr, 26, 784-787

14. Lee KH, Choi HS, Hwang KA, Song J (2016) Quality changes in Doenjang upon fermentation with two different Bacillus subtilis strains. J East Asian Soc Diet Life, 26, 163-170

15. Lee SY, Kim JY, Baek SY, Yeo SH, Koo BS, Park HY, Choi HS (2011) Isolation and characterization of oligotrophic strains with high enzyme activity from buckwheat Sokseongjang. Korean J Food Sci Technol, 43, 735-741

16. AOAC (1995) Official Methods of Analysis. $16^{\text {th }}$ ed, Association of Official Analytical Chemists, Washington DC, USA

17. Kang JE, Choi HS, Choi HS, Park SY, Song J, Choi JH, Yeo SH, Jung ST (2013) The quality characteristics of commercial Deonjang certified for traditional foods. Korean J Connumity Living Sci, 24, 537-542

18. Jin SK, Kim IS, Hah KH, Park KH, Kim IJ, Lee JR 
(2006) Changes of $\mathrm{pH}$, acidity, protease activity and microorganism on sauces using a Korean traditional seasonings during cold storage. Korean J Food Sci Ani Resour, 26, 159-165

19. Kim YS, Kim JY, Choi HS (2011) Quality characteristics of commercial rice soybean paste. Korean J Food Preserv, $18,853-858$

20. Lee SY, Baik SH, Ahn YJ, Song J, Kim JH, Choi HS (2013) Quality characteristics of commercial Korean types of fermented soybean sauces in China. Korean $\mathbf{J}$ Food Sci Technol, 45, 796-800

21. Kim HE, Han SY, Jung JB, Ko JM, Kim YS (2011) Quality characteristics of Doenjang (soybean paste) prepared with germinated regular soybean and black soybean. Korean J Food Sci Technol, 43, 361-368

22. Lee SY, Park NY, Kim JY, Choi HS (2012) Quality characteristics of rice-Doenjang during fermentation by differently shaped Meju and adding starter. Korean J Food Nutr, 25, 505-512

23. Lee GR, Ko YJ, Kim EJ, Kim IH, Shim KH, Kim YG, Ryu CH (2013) Quality characteristic of wheat Doenjang according to mixing ratio of Meju. Korean J Food Preserv, 20, 191-198

24. Min SH (2006) Quality characteristics of Doenjang containing Astragalus membranaceus water extracts. Korean J Food Cookery Sci, 22, 514-520

25. Kim JH, Yoo JS, Lee CH, Kim SY, Lee SK (2006) Quality properties of soybean pastes made from Meju with mold producing protease isolated from tradirional Meju. J Korean Soc Appl Biol Chem, 49, 7-14

26. Choi BY, Gil NY, Park SY, Kim SY (2016) Quality characteristics of Doenjang depending on various salt concentration during long-term fermentation period. Korean J Food Preserv, 23, 788-796

27. Park WP, Kim ND, Lee SC, Kim SY, Cho SH (2006) Effects of powder and concentrates of Prnus mume on the quality of Doenjang during fermentation. Korean J Food Preserv, 13, 574-580

28. Park JS, Lee MY, Lee TS (1995) Compositions of sugars and fatty acids in soybean paste (Doenjang) prepared with different microbial sources. J Korean Soc Food Nutr, 24, 917-924

29. Kim JH, Ahn HJ, Yook HS, Park HJ, Byun MW (2001) Biogenic amines content in commercial Korean traditional fermented soybean paste. Korean J Food Sci Technol, 33, 682-685

30. Rho JD, Choi SY, Lee SJ (2008) Quality characteristics of soybean pastes (Doenjang) prepared using different types of microorganisms and mixing ratios. Korean $\mathrm{J}$ Food Cookery Sci, 24, 243-250

31. Joo HK, Kim ND, Yoon KS (1989) Changes of enzymatic activities during the fermentation of soybean-soypaste by Aspergillus spp. J Korean Agric Chem Soc, 32, 295-302

32. Kim MJ, Rhee HS (1988) The compents of free amino acids nucleotides and their related compounds in soypaste made from native and improved Meju and soypaste product. J Korean Soc Food Nutr, 17, 69-72

33. An HS, Bae JS, Lee TS (1987) Comparison of free amino acids, sugars, and organic acids in soy bean paste prepared with various organisms. J Korean Agric Chem Soc, 30, 345-350

34. Ahn JB, Park JA, Jo HJ, Woo IH, Lee SH, Jang KI (2012) Quality characteristics and antioxidant activity of commercial Doenjang and traditional Doenjang in Korea. Korean J Food Nutr, 25, 142-148

35. Hwang JH, Oh YS, Lim JH, Park JE, Kim MB, Yoon HS, Lim SB (2009) Physiological properties of Jeju traditional Doenjang. J Korean Soc Food Sci Nutr, 38, 1656-1663

36. Lee JS, Kwon SJ, Chung SW, Choi YJ, Yoo JY, Chung DH (1996) Changes of microorganisms, enzyme activitis and major components during the fermentation of Korean traditional Doenjang and Kochujang. Kor J Appl Microbiol Biotechnol, 24, 247-253

37. Rhee CH, Lee JB, Jang SM (2000) Changes of microorganisms, enzyme activity and physiological functionality on the traditional Doenjang with various concentrations of Lentinus edodes during fermentation. J Korean Soc Agric Chem Biotechnol, 43, 277-284 